\title{
Urban Housing: Student Studies for Chicago
}

\author{
RONALD E. SCHMITT \\ University of Illinois at Urbana-Champaign \\ USA
}

\section{INTRODUCTION}

American cities are experiencing sprawling growth at the periphery and decline at the center. How to reverse this wasteful cycle and regenerate the city is difficult. Architects must participate in decision maklng that shapes our built environment. Architectural education must prepare future architects for this responsibility. Introduction of large-scale projects, with an emphasis on urban housing, is an integral and unselfconscious way to enable the student to gain understanding, appreciation, competence and confidence to deal with urban scale and issues. Large-scale urban housing, set in a Chicago context, has been the studio focus for several recent terms. Student studies from these investigations demonstrate creative possibilities in the process for urban revitalization and consolidation.

\section{THE SITUATION}

American cities are becoming "donuts" with sprawling growth at the periphery and decline at the center. This phenomenon is inefficient and wasteful in terms of human living patterns, energy resources, and land productivity. Overall, quality of life erodes for everyone. The environment further declines. Distances and distrust further inhibit communication between diverse populations despite technological advances in communication systems. Many herald these changes as inevitable progress. Architects embrace the commissions of dispersal with its often diluted forms and scale-less patterns. Starting with Frank Lloyd Wright, many architects have romanticized suburbs. ${ }^{1}$ Nostalgic longing for small town living and country homes permeates imagery produced by some present-day architects. This Disneylandish approach substitutes sentimentality for the reality of the urban condition.

\section{HOUSING MODELS HELP UNDERSTANDING OF URBAN DESIGN}

Architects must again participate in decision making that shapes our built environment. How to do this may be difficult. But it starts with an architectural education that introduces large-scale design so the student becomes adept and responsible for the civic-scale environment. Formal design pedagogy is balanced with other factors, which influence design decisions. A sense of reality is introduced through understanding social and economic factors. Studio projects stress large-scale housing for "real" sites in an urban context. The issues of community, social interaction and individuality are inherent in such projects. Exposure to alternative dwelling unit types is eye opening for students, many of whom are from suburbs and familiar only with detached single-family housing. More importantly, the choice of studio project conveys a message, i.e., a set of values. The study of large-scale urban housing helps the student understand issues and explore solutions to improve urban life and help preserve the identity of both city and countryside.

\section{CHICAGO CONTEXT}

Proximity to Chicago is one reason why that city becomes a setting for many urban housing studies in studio. Students can visit sites and experience the city. More importantly, Chicago, unlike many American cities, has been able to sustain the central city despite continuing outward expansion and pressures of decentralization. There is an established precedent for large-scale housing and urban vitality. Therefore, Chicago has become a setting for urban housing studies. Student designs range urban residential types. These include: highrise mixed-use, mid-rise mixed-use, and scattered sites public housing. Each study was done by an individual, who was either a fourth- or fifth-year student. Projects were usually of five- or ten-week duration. More importantly, these projects represent viable alternatives to suburban sprawl.

\section{HIGHRISE MIXED-USE}

The focus of study for several semesters has been mixed-use highrises. Mixed-use, which integrates residential with commercial, office and parking, is a building type common to Chicago. The introduction of residential populates the site on a 24-hour basis and helps support commercial activity. 
Vacant or underused sites, ripe for development and located near the "Loop," have been utilized (the Loop is Chicago's downtown). Proximity to the Loop not only makes such high-density development feasible but helps reinforce the vitality of the downtown. Furthermore, most of the selected sites front on the river. The Chicago River, as it cuts through the blocks of the city, liberates design from the imposed order of the street grid. More importantly, the natural resource of water can become a highly-valued asset. Such features must be exploited in competition with suburbia. Legislative control of suburban sprawl is not possible in America. Therefore, housing in the city must have more desirability than suburban units to effectively compete in the metropolitan housing market.

The immense scale of mixed-use highrise is initially difficult for students to grasp; however, they are soon able to manipulate the program into creative architectural explorations. For a riverfront location, where a parking structure now inappropriately sits, there were a range of designs. This particular site has been studied several times as the immediate context has changed over a short period.

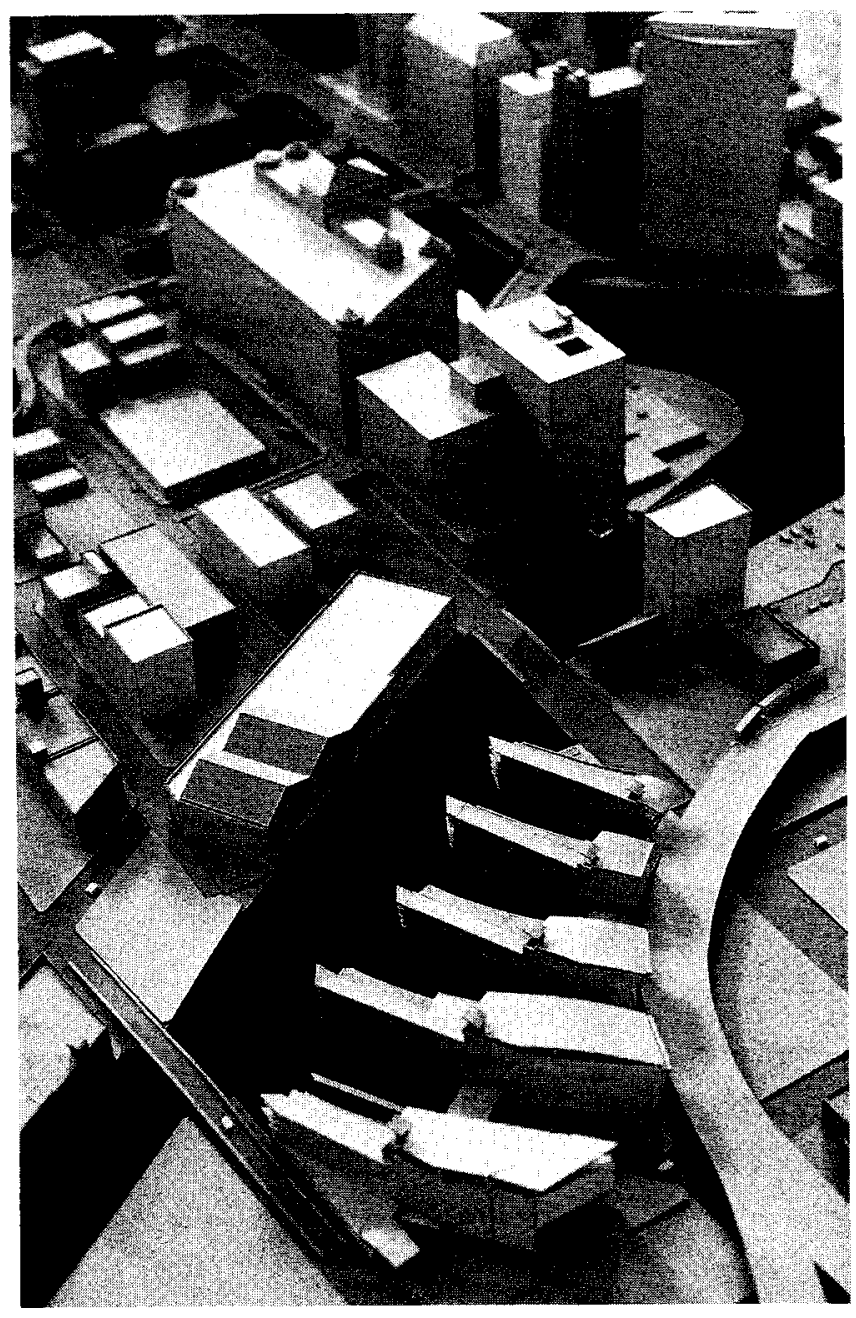

Fig. 1. Mixed-use highrise design by Helen Stoner for two-thirds of the city block on the Chicago River between Wells and LaSalle Streets (Spring 1990).

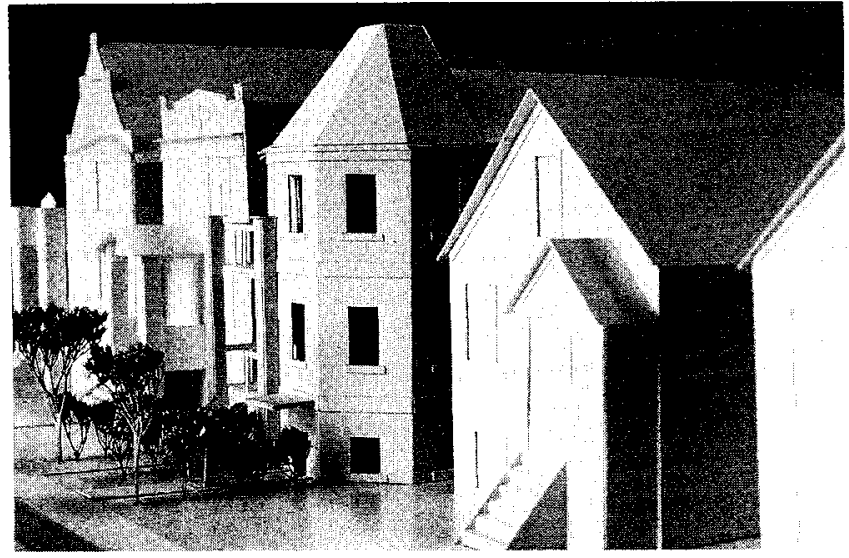

Fig. 2. Mixed-use highrise design by Cindy Eng for approximately one-half of the city block on the Chicago River between Wells and LaSalle Streets (Spring 1993).

In addition, the site offered a typically Chicago problem of building on "air-rights" above a railroad track. An added value of mixed-use projects is the direct comparison of the various programmatic uses, such as differing functional requirements, modules and structural demands. More importantly, the underlying urban issues become clearly apparent and comprehensible.

The dramatic Wolf Point location at the river's junction was the site for another mixed-use complex. The site is both highly visible and offers spectacular views. Again, dwelling units combined with office, commercial, parking and marina. Most students articulated major uses. Some put primary uses in separate structures. A round residential tower was composed with a back-drop of office buildings. Some stacked residential above office while a few tried more integration. For example, in a building, which curved with the river, a residential slab terminated the horizontal layering of different uses. A marina, vehicular ramps, and pedestrian promenades were located between the building and the existing Apparel Mart. With the crash of the office market nationwide and especially in Chicago, it seemed appropriate to strike office use from the mix. Subsequently, housing became the major focus but the introduction of mixed-uses continued as desirable components. However, a more humanistic form and scale, one with horizontal proportions rather than vertical emphasis, seemed appropriate to explore. Chicago needs such mid-rise housing as a transition between the typical residential construction of townhouses and highrises.

\section{MID-RISE MIXED-USE IN RIVER NORTH}

The River North District has become fashionable. Most remaining warehouse structures have been converted to residential lofts, studios, art galleries and shops. A misused city block became the site for a 200-dwelling unit mid-rise and included mixed-uses. Students confronted the pivotal location between highrises and more human-scaled warehouse conversions. Articulation along Hubbard Street re- 
sponded to the scale of older building frontages. At the same time, the one remaining building on site was engaged. Students addressed the former City Court Building of Romanesque Style (Otto Matz, 1892). Several created a civicspace, which focused on the historic landmark. Taller masses tended to be shifted to the edge of the site as a transitional buffer between highrises and smaller-scale buildings as well as to offer better views of the Loop.

\section{SCATTERED SITES PUBLIC HOUSING}

Another form of urban housing, but on a different scale, was explored in Fall 1994. Public housing projects in America and especially in Chicago have been failures. This has been well documented. The Chicago Housing Authority has a scattered sites public housing program administered by the Habitat Company and is a promising alternative. Smallscale housing is built as infill in stable neighborhoods. The program stipulates populations in these neighborhoods cannot exceed $30 \%$ minorities. This is an attempt to integrate and disperse public housing ghettos. The Habitat Company has employed prominent Chicago architects to upgrade design but has requested contextual images to fit into older neighborhoods. ${ }^{2}$ We worked with the Habitat Company for six scattered sites in the West Town neighborhood. Three dwelling units were proposed for each site. Parcels were typically 25 feet wide by 125 feet long although one was wider to accommodate a unit for the disabled. Conformance to zoning restrictions and economical construction were mandatory although HUD requirements were relaxed. Many students followed the Habitat Company program but some questioned the historical image conformity and opted for more exploratory designs. Several offered social alternatives such as co-op housing. One student derived a "thinhouse" of only twelve feet in width. The increased side-yard setbacks eliminated fire-rating requirements for exterior walls and allowed cheaper construction. It was also intended to be manufactured in modules and trucked to the site. A shared great room and roof-sheltered play deck were features of the cooperative venture.

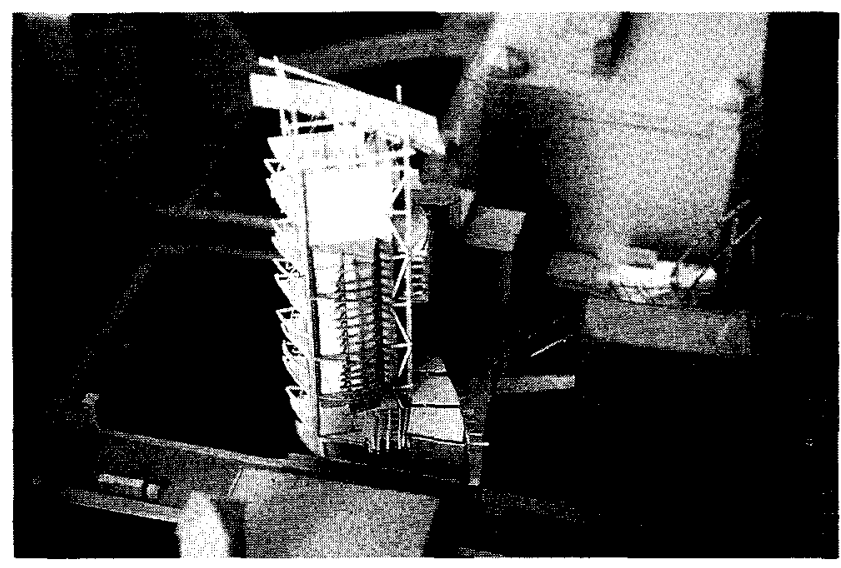

Fig. 3. Scattered Site Public Housing by Miguel Rodreguez. Infill design on S. Troy Street, West Town Neighborhood (Fall 1994).

\section{MID-RISE MIXED-USE ON THE CHICAGO RIVER}

As stated earlier, riveredge sites have been utilized in order to provide additional amenities. Furthermore, this is an attempt to reclaim and revitalize the river corridor, where shipping and industrial development once concentrated. For example, a site near Wolf Point on the north branch of the Chicago River was industrial but is now surface parking. Harry Weese proposed mixed-use eighteen years ago for this river segment but only a warehouse conversion for residential lofts and a few townhouses were realized. Our study proposed $440 \mathrm{dwelling}$ units and other uses for the seven acre site. All students provided public access to the river with promenades and gathering spaces. Some reestablished a hard riveredge while others softened the image. One scheme introduced the basic Chicago street grid but it was modified as eroded by the river. Several attempted recollection of an industrial image, which one student exploited in a series of pierhouses. An urban-scaled framework balanced the rhythmic composition with the nearby massive buildings. Within that framework, human-scale was introduced. Boathouses and door-step parking were integrated into the buildings.

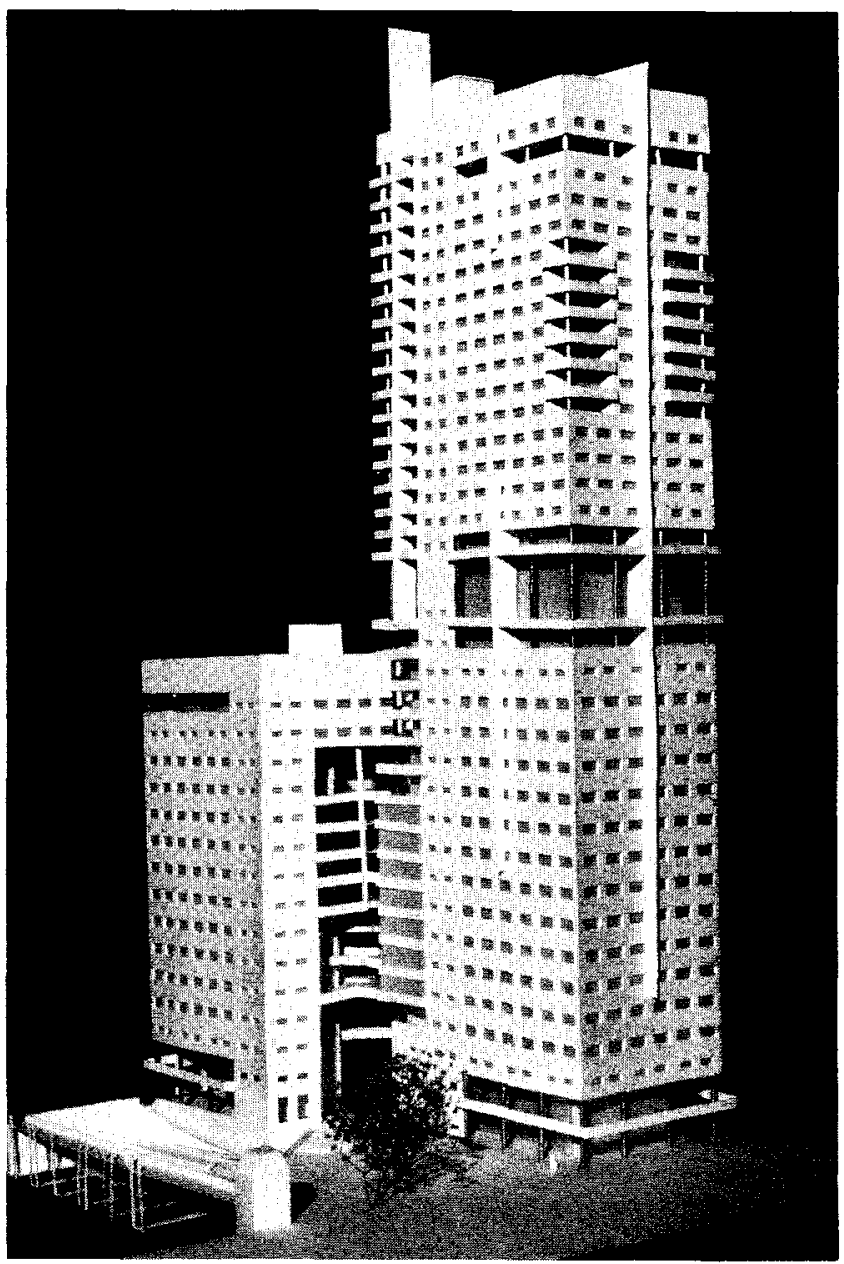

Fig. 4. "Pierhouses," mid-rise mixed-use design by Timothy Bicknell for the North Branch of the Chicago River between Kinzie Street and Grand Avenue (Fall 1994). 


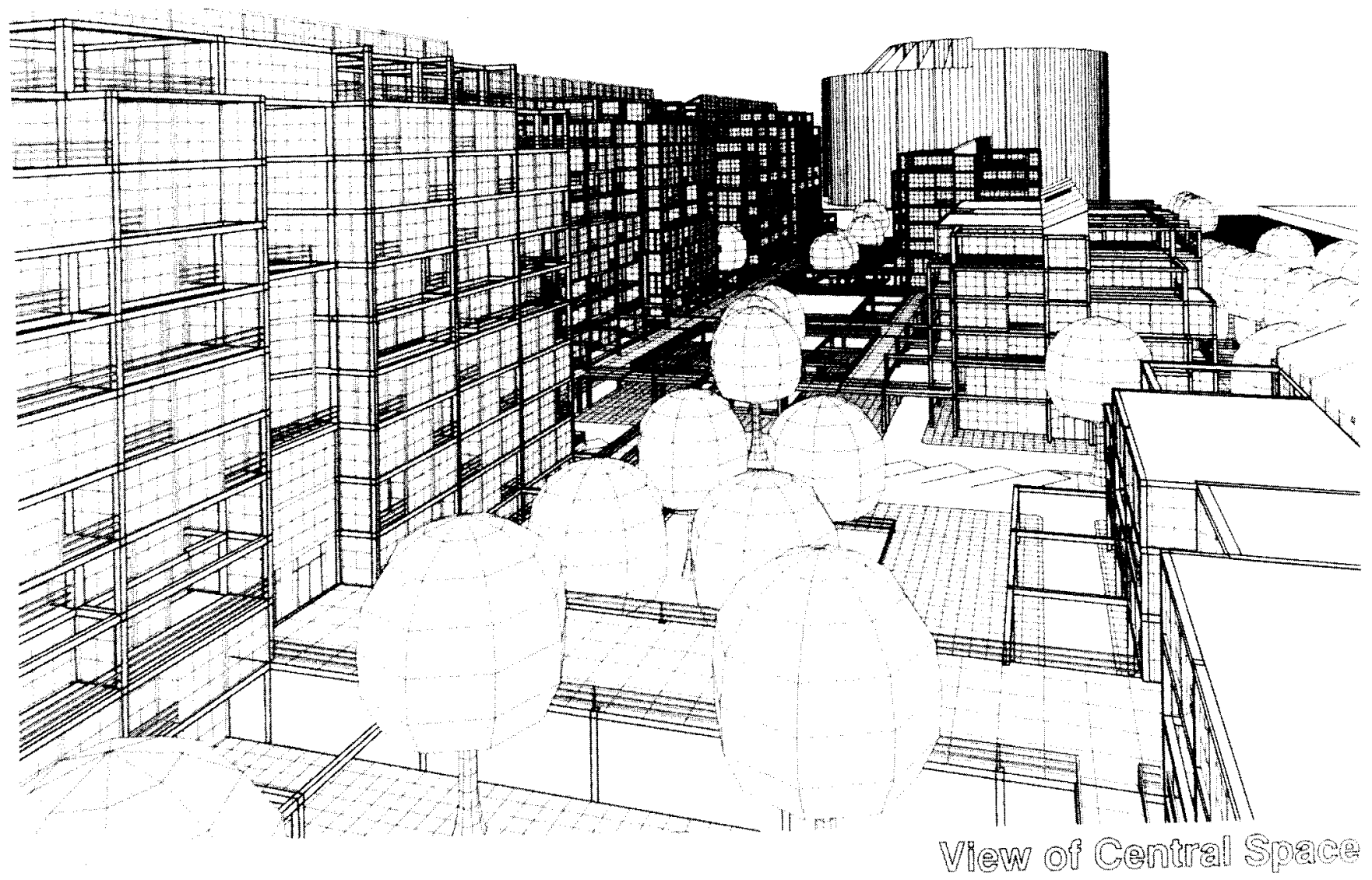

Fig. 5. Mid-rise mixed-use design by Miguel Rodreguez. Located on the North Branch of the Chicago River (Fall 1994).

Edge conditions, nautical associations, appropriate scales and attractive living environments were among design factors considered by all students.

This past semester, a similar study used another waterfront setting, this time on the river's south branch and the site of a former rail-yard and demolished train station. The site offered dramatic views northward to the Loop. Architect Bertrand Goldberg proposed three 70 -story residential towers on the site as a terminus for his mixed-use multi-curved River City. However, only the initial phase of the serpentine River City (1984) proposal has been realized. Student designs introduced public promenades and, in many cases, linear parks to reinforce the river as an urban path and natural attraction. The river, like Lake Michigan, becomes an armature for public recreation and high-density residential.

Although site forces and urban responses in design have been stressed in this paper, internal organization, livability and especially dwelling unit variations were balanced factors. Inclusion of a variety of dwelling unit types was stressed in order to attract diverse populations. Students were encouraged to explore alternatives to the conventional Chicago apartment, with its stretched-out plan and eightfoot high ceilings of flat-slab concrete. The concluding project of the semester was to infill across the street on surface parking lots and in between existing residential loft structures. New uses included residential, retail-commercial and parking.

In summary, the challenge has been to meld high density residential with other uses; exploit the potential of the specific site; be sensitive to urban scale and context; and attempt to design a provocative statement in the historically creative spirit of Chicago architecture. In addition, many of these student studies have value as models for urban housing and could provide desirable alternatives to living patterns based on outward sprawl.

\section{NOTES}

"Broadacre City" (1934-1958). Wright's Broadacre City concept has been covered in many publications. Its most complete description is probably in the book, Frank Lloyd Wright, The Living City (NY: Horizon Press, 1958).

2 Representative designs by various Chicago architects appeared in the exhibit, Solutions: Reinventing Public Housing, displayed at the ArchiCenter of the Chicago Architecture Foundation, June-September 1994. The Scattered Sites Public Housing Program and some designs are summarized in the exhibition catalog book Solutions: Reinventing Public Housing (Chicago: Business and Professional People for the Public Interest, 1994). Information about the exhibit or catalog can be addressed to: The Habitat Company, 350 West Hubbard Street, Chicago, IL 60610 


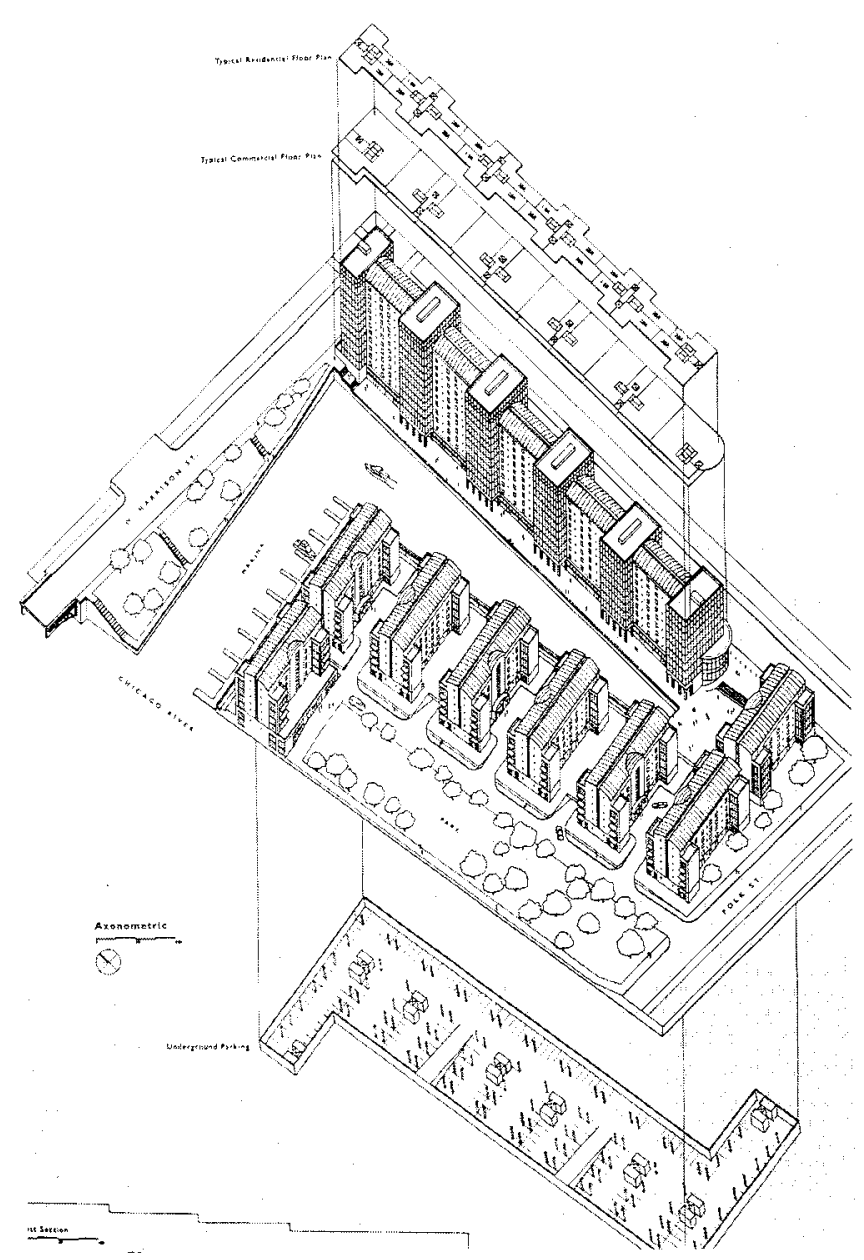

Fig. 6. Mid-rise mixed-use design by Mark Witte.- Located on the South Branch of the Chicago River at Harrison and Wells Street (Spring 1995).

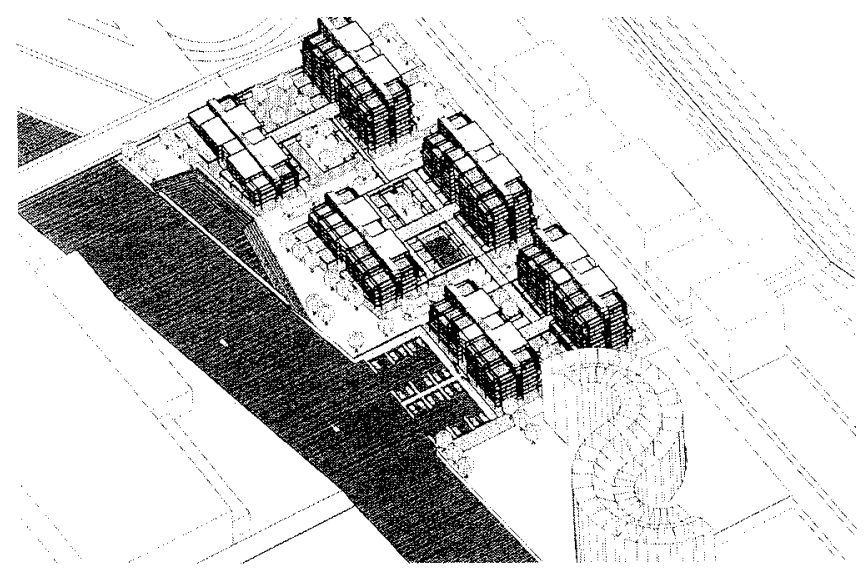

Figs. 7A. Mid-rise mixed-use design by Michael Lingertat. Interfaces with Bertrand Goldberg's curvilinear River City and integrates with the river (Spring 1995).

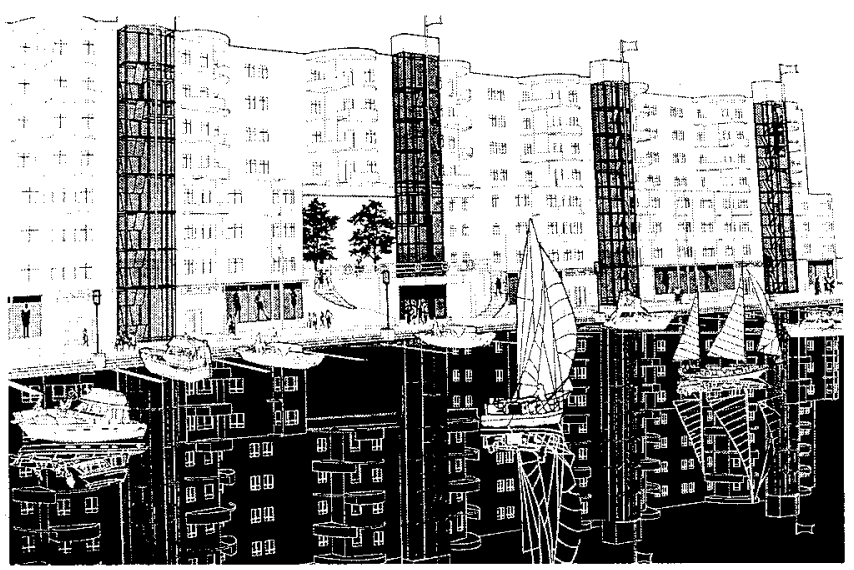

Figs. 7B. Mid-rise mixed-use design by Michael Lingertat. Interfaces with Bertrand Goldberg's curvilinear River City and integrates with the river (Spring 1995). 